\title{
Analysis of epidemiological factors for pelvic floor defects in Indian women
}

\author{
Maitreyee S. Parulekar*, Shashank V. Parulekar
}

Department of Obstetrics and Gynecology, Seth G. S. Medical College and K. E. M. Hospital, Mumbai, Maharashtra, India

Received: 21 March 2020

Accepted: 22 April 2020

*Correspondence:

Dr. Maitreyee S. Parulekar, E-mail: mtry19@gmail.com

Copyright: (c) the author(s), publisher and licensee Medip Academy. This is an open-access article distributed under the terms of the Creative Commons Attribution Non-Commercial License, which permits unrestricted non-commercial use, distribution, and reproduction in any medium, provided the original work is properly cited.

\section{ABSTRACT}

Background: Pelvic floor defects is one of the commonest conditions requiring gynecological reference. This study was aimed at evaluation of epidemiology which would help us in having a better understanding regarding the prevalence, risk factors, the natural course and associated complications of the disease in Indian women where the number of women presenting with pelvic floor defects is on a rise but there is a considerable lack of research in literature as compared to the western population.

Methods: It was an observational, non-interventional, prospective type of study including 88 patients over a period of 3 years at the department of obstetrics and gynecology at a tertiary hospital in Mumbai, Maharashtra, India.

Results: The mean age of the patients was $52.38 \pm 11.35$ years, $54(61.36 \%)$ of the patients were of postmenopausal age group. The mean duration for which the complaints were present were $48 \pm 6.73$ months. Seventy-six patients $(86.83 \%)$ presented with complaints of mass per vagina, 22 patients $(25 \%)$ had history of prolonged labor and 9 patients $(10.2 \%)$ had history of instrumental delivery. Eighty-six women $(97.72 \%)$ had history of all vaginal deliveries and only 4 (4.54\%) patients had history of a caesarean section. Forty-four patients $(55.69 \%)$ of patients had grade 3 utero-vaginal descent, 74 patients $(84.09 \%)$ presented with cystocele and $79(89.77 \%)$ of the patients presented with rectocele.

Conclusions: This paper provides an insight into the factors affecting the prevalence of this disease in Indian women and the unique differences from other populations.

Keywords: Epidemiology, Pelvic floor defects, Pelvic organ prolapse

\section{INTRODUCTION}

Pelvic floor is a complex arrangement of different muscles and ligaments and fascia. The defects in them or the nerves supplying the muscles leads to prolapse of different organs like uterus, vagina, bladder, intestines together termed as 'pelvic organ prolapse'. 'Large number of combinations and variations are observed in pelvic floor defects, leading to a wide range of symptoms such as pelvic pain, chronic discharge, bleeding from ulceration, associated urinary and defecation symptoms, sexual dysfunction; but the most specific of them all being protrusion in vagina. Estimated prevalence of pelvic organ prolapse is almost $50 \%$ women of which $10-$ $20 \%$ seek treatment for the same. ${ }^{2}$ Pelvic floor defects result from a wide number of etiological factors: predisposing factors such as a consequence of pregnancy due to hormonal or mechanical effects, as a consequence of labour and childbirth due to trauma to pelvic muscles or injury to nerves supplying these muscles. ${ }^{3,4}$ Advancing age is an important contributing factor due to weakening of pelvic floor muscles and decreased estrogen levels with age leading to muscle atrophy., ${ }^{5,6}$ Diabetic neuropathy, chronic corticosteroid therapy for different medical conditions causing weakening of connective tissue, smoking as it exerts an anti- estrogenic effect as 
well as leads to chronic coughing, and connective tissue disorders are the other important predisposing factors. ${ }^{4,7,8}$ Precipitating factors which play a role in pelvic organ prolapse are increased abdominal pressure due to obesity, chronic cough, strenuous work, long standing pelvic tumours, and long standing ascites. Damage to proximal (apical) suspension by cardinal-uterosacral ligament complex leads to uterovaginal prolapse, vaginal vault prolapses in post hysterectomy status and enterocele. Damage to the mid-vaginal support i.e. lateral attachment of pubocervical and rectovaginal fascia to arcus tendinous fascia pelvis and arcus tendinous fascia rectovaginalis respectively, leads to paravaginal and para rectal defects. Damage to fusion of deep endopelvic fascia to urogenital diaphragm and perineal body may lead to urinary incontinence and defecatory dysfunction. ${ }^{2,9}$ Although this is a widespread problem affecting millions of women, with significant morbidity and deterioration of lifestyle, however exact prevalence is not known as many cases do not present with symptoms. This study was aimed at studying all the epidemiological factors related to pelvic organ prolapse as it would help in identification of modifiable risk factors which would help us in counselling the patients and formulating some measures for prevention, it would help in early identification of pelvic organ prolapse in high risk patients which would prevent complications, it would also contribute in selecting different treatment modalities for such patients and also to scientific literature.

\section{METHODS}

It was an observational, non-interventional, prospective study conducted in the department of obstetrics and gynecology at a tertiary hospital in India from August 2016 - August 2018.

\section{Inclusion criteria}

- The study population included 88 women with defects of pelvic floor and resulting pelvic organ prolapse of age above 18 years admitted in the hospital for treatment after taking their informed consent.

\section{Exclusion criteria}

- Pregnant women or women in puerperium or post abortal state were excluded from the study.

Data for case record form was taken as follows.

- $\quad$ Age, address, marital status

- Presenting complaints

- Menstrual history (present, past)

- Sexual history

- Obstetric history with details of each pregnancy (mode of delivery, complications during childbirth, location of delivery)
- Significant medical/surgical history including any genital or urinary tract surgery

- Personal history to look for addictions like tobacco chewing, smoking, 'Mishri' application for cleaning teeth which contains tobacco.

- Family history

- Bowel-bladder disturbances

- General examination of the patient was done including height, weight, body mass index (BMI) in kilogram per metre squared, vitals of the patient were taken.

- Systemic examination including respiratory, cardiovascular, abdominal and detailed pelvic examination for prolapse was performed. With the help of a Sim's speculum and anterior vaginal wall retractor, patient was asked to perform Valsalva manoeuvre or to strain and points of maximum protrusion were noted in each compartment (central/anterior/posterior) and grading was done as per Baden-walker classification.

Investigations (haematological or radiological) were not required for collection of epidemiological data and clinical diagnosis. Pap smear was done in all cases, endometrial aspiration in patients with abnormal uterine bleeding and ultrasound of pelvis and kidney-ureterbladder (KUB) and urine examination were done in patients if any urinary symptoms or complications were suspected.

\section{Statistical analysis}

The data in our study has been analysed using the computer program Microsoft excel 2017 (Microsoft Corporation, NY, USA). Continuous variables were described as mean and variation of each observation from the mean value (Standard Deviation) represented as Mean \pm SD. Categorical variables were described by taking percentages.

\section{RESULTS}

\section{Demographic details}

A total of 88 patients were enrolled in the study. The mean age of the patients was $52.38 \pm 11.35$ years. The maximum number of patients who presented with pelvic floor defects in our study were in the age group between 60-64 years (17.04\%), youngest being of 30 years of age and oldest of 74 years. Demographic details are illustrated in Table 1 .

\section{Presenting complaints}

A total of 76 patients presented with mass per vagina as the primary complaint $(86.83 \%)$. Of all the 88 patients, 16 had menorrhagia (18.18\%), 13 patients (14.77\%) complained of constipation or straining at stools needing digital pressure for evacuation, 13 patients $(14.77 \%)$ with 
dyspareunia, $11(12.5 \%)$ patients with voiding difficulties and required digitation, 11 patients (12.5\%) with complaints of burning micturition, increased frequency and urgency. Two out of $88(2.27 \%)$ patients had presented with stress urinary incontinence while 3 patients $(3.40 \%)$ presented with acute urinary retention which required urgent urinary catheterization and uroflowmetry studies preoperatively as illustrated in Figure 1.

Table 1: Mean age at presentation.

\begin{tabular}{|l|ll|}
\hline Age in years & Number of patients & Percentage \\
\hline $30-34$ & 5 & $5.68 \%$ \\
\hline $35-39$ & 6 & $6.81 \%$ \\
\hline $40-44$ & 12 & $13.63 \%$ \\
\hline $45-49$ & 11 & $12.5 \%$ \\
\hline $50-54$ & 13 & $14.77 \%$ \\
\hline $55-59$ & 8 & $9.09 \%$ \\
\hline $60-64$ & 15 & $17.04 \%$ \\
\hline $65-69$ & 11 & $12.5 \%$ \\
\hline 70 and above & 7 & $7.95 \%$ \\
\hline
\end{tabular}

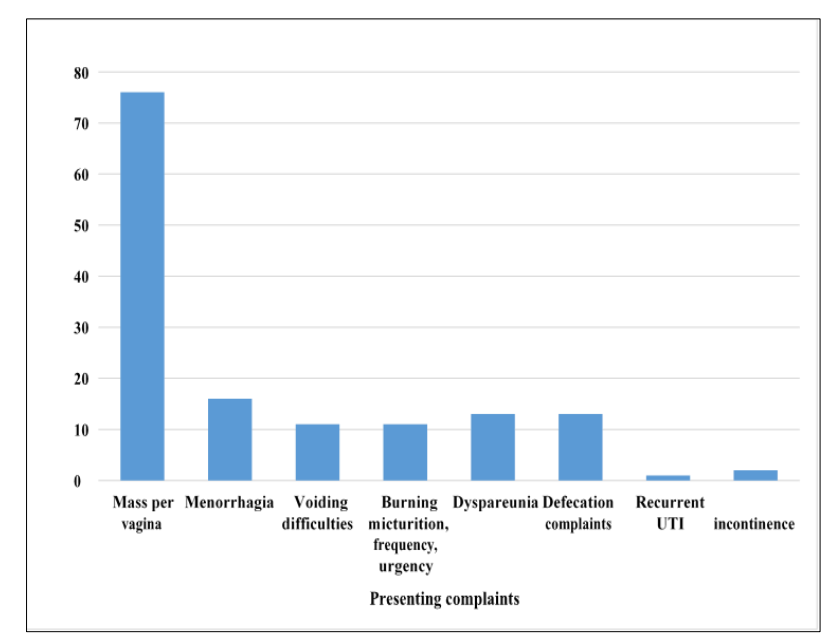

Figure 1: Presenting complaints.

\section{Medical and surgical history}

A total of 26 out of 88 patients (29.54\%) had history of hypertension, while $18(20.4 \%)$ had history of diabetes mellitus. Twelve patients $(13.6 \%)$ had anemia severe enough to need blood transfusions. Eight patients $(9.09 \%)$ had history of pelvic inflammatory disease. Nine patients $(10.22 \%)$ who presented with urinary complaints were diagnosed with urinary tract infections and were treated with antibiotics as per culture and sensitivity.

Two patients $(2.27 \%)$ with chronic kidney disease and 1 patient $(1.13 \%)$ with nephrotic syndrome were on chronic oral corticosteroid therapy, whereas 3 patients $(3.40 \%)$ with bronchial asthma were on chronic inhalational steroid therapy. One patient $(1.13 \%)$ was diagnosed with acute kidney disease. Four $(4.54 \%)$ had history of pulmonary tuberculosis. Eighteen patients $(20.45 \%)$ had incidental history of tubal ligation and 3 patients (3.40\%) had history of prior abdominal hysterectomy and 1 patient had history of vaginal hysterectomy. Six patients $(6.81 \%)$ had some cardiovascular ailments while 4 $(4.54 \%)$ had hypothyroidism.

One patient $(1.13 \%)$ had ANA positive status (Young nulliparous prolapse) who would need further evaluation over time to rule out connective tissue disorder. Details are illustrated in Table 2.

Table 2: Medical/surgical history.

\begin{tabular}{|lll|}
\hline Type of history & $\begin{array}{c}\text { Frequency } \\
\text { (out of 88) }\end{array}$ & Percentage \\
\hline Hypertension & 26 & $29.54 \%$ \\
\hline Diabetes mellitus & 18 & $20.45 \%$ \\
\hline Tubal ligation & 18 & $20.45 \%$ \\
\hline $\begin{array}{l}\text { Pelvic inflammatory } \\
\text { disease }\end{array}$ & 8 & $9.09 \%$ \\
\hline Hypothyroidism & 4 & $4.54 \%$ \\
\hline Tuberculosis & 4 & $4.54 \%$ \\
\hline Bronchial asthma & 3 & $3.40 \%$ \\
\hline Ectopic pregnancy & 2 & $2.72 \%$ \\
\hline Cardiovascular ailments & 6 & $6.81 \%$ \\
\hline Urinary tract infection & 9 & $10.22 \%$ \\
\hline $\begin{array}{l}\text { Total abdominal } \\
\text { hysterectomy }\end{array}$ & 3 & $3.40 \%$ \\
\hline Acute kidney disease & 1 & $1.13 \%$ \\
\hline Chronic kidney disease & 2 & $2.27 \%$ \\
\hline ANA positive & 1 & $1.13 \%$ \\
\hline Anemia & 12 & $13.6 \%$ \\
\hline Cystitis & 1 & $1.13 \%$ \\
\hline
\end{tabular}

Table 3: Predisposing and precipitating factors based on history.

\begin{tabular}{|l|l|l|}
\hline Complaints & $\begin{array}{l}\text { Frequency } \\
\text { (out of 88) }\end{array}$ & Percentage \\
\hline Obesity & 7 & $7.9 \%$ \\
\hline Tobacco chewing & 7 & $7.9 \%$ \\
\hline Steroid Therapy & 6 & $6.81 \%$ \\
\hline Prolonged labor & 22 & $25 \%$ \\
\hline Instrumental delivery & 9 & $10.2 \%$ \\
\hline Chronic cough & 5 & $5.6 \%$ \\
\hline Chronic constipation & 13 & $14.7 \%$ \\
\hline $\begin{array}{l}\text { Long standing ascites, } \\
\text { pelvic tumors }\end{array}$ & 0 & $0 \%$ \\
\hline
\end{tabular}

\section{Predisposing and precipitating factors}

Of all the patients, $22(25 \%)$ gave a history of prolonged labour while 13 of them $(14.7 \%)$ had history of chronic constipation. Seven out of 88 patients (7.9\%) had increased BMI (>24.9).

The other factors are illustrated in the following Table 3. 


\section{Menstrual history}

Fifty four out of 88 patients $(61.36 \%)$ were postmenopausal, $18(20.45 \%)$ patients had history of abnormal uterine bleeding whereas 12 (13.63\%) patients had normal menstrual cycles. Four patients (4.54 \%) who were post hysterectomy had surgical menopause.

\section{Obstetric history}

On calculation of median parity and living issues, authors found that to be 3 (range 0-8) for both the parameters. There was only one nulligravida amongst 88 patients in this study. Maximum parity was 8 with 8 living issues. 20 patients $(23 \%)$ had history of IUFD/stillbirths while 5 patients had reported medical termination of pregnancy.

\section{Mode of delivery}

Eighty-seven of the total 88 patients $(98.86 \%)$ in the study had delivered a fetus at least once. Eighty-six of these 87 patients had at least one normal vaginal delivery. Nine out of these 86 patients had undergone instrumental delivery. Four out of 87 patients also had at least one lower segment caesarean section delivery. Twenty-two out of 86 patients gave a positive history of prolonged and difficult labor. Distribution illustrated in Table 4.

Table 4: Mode of delivery.

\begin{tabular}{|lll|}
\hline Feature & $\begin{array}{l}\text { Frequency } \\
\text { (out of 88) }\end{array}$ & Percentage \\
\hline $\begin{array}{l}\text { Total number of patients } \\
\text { with at least one delivery }\end{array}$ & 87 & $98.86 \%$ \\
\hline Vaginal delivery & 86 & $97.72 \%$ \\
\hline Instrumental delivery & 9 & $10.22 \%$ \\
\hline LSCS & 4 & $4.54 \%$ \\
\hline Prolonged labor history & 22 & $25 \%$ \\
\hline
\end{tabular}

\section{Location of delivery}

Forty-nine patients $(55.68 \%)$ out of total patients had all their deliveries conducted at a hospital, 31 patients $(35.22 \%)$ had all their deliveries conducted at home whereas 7 women $(7.95 \%)$ had their deliveries conducted both at home and a hospital in their obstetrical history. In twenty $(64.51 \%)$ of these homes delivered patients the deliveries were conducted by midwives/trained dais and $11(35.48 \%)$ of the deliveries were conducted by untrained personnel.

\section{Grades of prolapse}

On per speculum examination, the utero-vaginal descent grading was done. Nine patients $(10.22 \%)$ had no uterovaginal descent. Seventy-nine patients $(89.77 \%)$ had different grades of uterine descent. Ten patients $(12.65 \%)$ had grade 1 prolapse, $21(26.58 \%)$ had grade 2 prolapse and it was found that majority of the descents $(55.69 \%)$ belonged to grade 3 . A total of $74(84.09 \%)$ patients presented with cystocoele. Three patients $(4.05 \%)$ had grade 1 cystocele, $36(48.64 \%)$ had grade 2 and 35 $(47.29 \%)$ had grade 3 cystocele. Seventy-Nine $(89.77 \%)$ of the total patients presented with rectocele on per speculum examination. Fourteen of them (17.72\%) had grade 1 rectocele, 50 patients $(63.29 \%)$ had grade 2 rectocele and 15 patients $(18.98 \%)$ had grade 3 .

\section{DISCUSSION}

The healthcare utilization for pelvic floor defects is predicted to grow as the population ages. The total number of women who will undergo surgery for pelvic organ prolapse is estimated to increase by $48.2 \%$ over the four decades (from 2010 to 2050) as per the study conducted by $\mathrm{Wu}$ and colleagues. ${ }^{10}$ Hence in order to have a better understanding of this problem in its entirety, this epidemiological study of different pelvic floor defects was conducted at our institute. As per the NHANES study conducted in USA in 2005-2006, the prevalence of pelvic organ prolapse was $2.9 \%, 15.7 \%$ women suffered from urinary incontinence and $9 \%$ from faecal symptoms. ${ }^{11}$

A study conducted by Rorveit et al, 5.7\% women had symptomatic pelvic organ prolapse. But both of these studies were symptom-based studies where questionnaire-based survey was done, hence details about types of pelvic organ prolapse i.e. prevalence of cystocele, rectocele and grades of prolapse could not be obtained. ${ }^{12}$ An examination based study conducted by Swift et al, showed prevalence of uterine prolapse as follows: grade $1-43.3 \%$, grade $2-47.7 \%$, grade $3-2.6 \% .^{13}$ The difference between the prevalence of different pelvic floor defects in symptom based and examination based studies is because many women with pelvic organ prolapse are asymptomatic and severity of symptoms does not correlate well with the severity of prolapse, there has always been a discrepancy between physical examination and symptoms. ${ }^{14}$ Comparisons between mean age and different precipitating/predisposing factors between our study and other studies is illustrated in Table 5.

In all the above studies, increasing age and increasing parity showed significant associations with pelvic floor defects and our study showed similar results. The number of women with history of smoking/tobacco chewing in our study was less as compared to other studies discussed in table no, probably because the prevalence of smoking/tobacco chewing in Indian women is less as compared to western countries due to cultural inhibitions. Although we still found $7.9 \%$ association between tobacco chewing/application in the form of tooth powder and prolapse. Few studies as discussed above show a significant association between raised BMI and prolapse, others do not, needs further research to label it as a causative factor. It is an important risk factor that should be evaluated as it could be one of the modifiable factors. 
Amongst the non-modifiable risk factors, important association was found with old age and postmenopausal status. $61.36 \%$ patients in the current study were postmenopausal. After menopause there is estrogen deficiency that sets in which leads to atrophy of muscles of pelvic floor, also kyphotic changed secondary to osteoporosis contribute to the more horizontal shift of the pelvic brim leading to increased chances of prolapse. ${ }^{15}$

Table 5: Comparison of mean age and different predisposing/precipitating factors between our study and other studies in literature.

\begin{tabular}{|c|c|c|c|c|c|}
\hline $\begin{array}{l}\text { Predisposing/ } \\
\text { precipitating factors } \\
\text { for pelvic floor } \\
\text { dysfunction }\end{array}$ & $\begin{array}{l}\text { Durnea CM } \\
\text { et al }\end{array}$ & R-risk cohort (Kaiser) ${ }^{18}$ & $\begin{array}{l}\text { Miedel A } \\
\text { et } \text { al }^{19}\end{array}$ & Wu JM et $\mathbf{a l}^{10}$ & $\begin{array}{l}\text { Present } \\
\text { study }\end{array}$ \\
\hline Mean age in years & 31.2 years & $\begin{array}{l}55.7 \pm 8.6 \\
\text { years }\end{array}$ & 53.3 years & $\begin{array}{l}52.7 \% \text { in } 80 \\
\text { years or older }\end{array}$ & $\begin{array}{l}52.38 \pm 11.35 \\
\text { years }\end{array}$ \\
\hline Race/ethnicity & $\begin{array}{l}\text { Caucasians- } \\
99.5 \%\end{array}$ & $\begin{array}{l}\text { White population- } 55 \% \\
\text { African American-19\% }\end{array}$ & & $\begin{array}{l}\text { White } \\
\text { population } 70 \%\end{array}$ & $\begin{array}{l}\text { Asian } \\
\text { (Indian) }\end{array}$ \\
\hline $\mathrm{BMI}(>25)$ & $47.1 \%$ & $52 \%$ & $49.45 \%$ & $57.6 \%$ & $7.9 \%$ \\
\hline Prior hysterectomy & Not studied & $27 \%$ & Not studied & 5.4 & $4.54 \%$ \\
\hline Parity (mean) & Not studied & $2.5 \pm 1.4$ & 2.1 & $\begin{array}{l}33.6 \% 4 \text { or } \\
\text { more parity }\end{array}$ & 3 \\
\hline $\begin{array}{l}\text { Smoking /tobacco } \\
\text { chewing }\end{array}$ & $26.8 \%$ & $22 \%$ & $55.31 \%$ & Not studied & $7.9 \%$ \\
\hline $\begin{array}{l}\text { Chronic cough/COPD/ } \\
\text { asthma }\end{array}$ & Not studied & $5 \%$ & $15.38 \%$ & Not studied & $5.6 \%$ \\
\hline $\begin{array}{l}\text { Chronic constipation/ } \\
\text { straining at stools }\end{array}$ & Not studied & $80 \%$ & $79 \%$ & Not studied & $14.7 \%$ \\
\hline Diabetes & Not studied & $7 \%$ & Not studied & Not studied & $20.45 \%$ \\
\hline
\end{tabular}

Table 6: Comparison between presenting complaints in patients with pelvic organ prolapse.

\begin{tabular}{|lll|}
\hline Presenting complaints (\%) & Study by Barber MID et al & Current study \\
\hline Prolapse or bulge & 100 & $86.83 \%$ \\
\hline Urinary stress incontinence & 2 & $1.13 \%$ \\
\hline Voiding dysfunction and other urinary complaints & 59 & $28.4 \%$ \\
\hline Splinting to void & 17 & $12.5 \%$ \\
\hline Abnormal uterine bleeding & 0 & $18.18 \%$ \\
\hline Dyspareunia & Not studied & $14.77 \%$ \\
\hline Straining during defecation/ splinting during defecation & $26 / 20$ & $14.77 \%$ \\
\hline
\end{tabular}

Vaginal deliveries (normal as well as instrumental) were associated with maximum number of pelvic floor defects, in our study $98.86 \%$ women had vaginal deliveries out of which $10.22 \%$ had history of at least one instrumental delivery and the findings were consistent with older studies like the one conducted by Durnea CM et al which showed that $63 \%$ cases of cystocele had normal vaginal deliveries, $25.82 \%$ had instrumental deliveries whereas $83.80 \%$ of cases with rectocele had normal vaginal deliveries and $13.38 \%$ had instrumental deliveries. ${ }^{16}$ Only $4.54 \%$ patients had history of at least one caesarean section in this study group. Hence the relation between histories of vaginal deliveries, prolonged labour and associated injuries to levator ani group of muscles or the nerves supplying them and pelvic organ prolapse was very well documented in our study. $25 \%$ cases in our study had history of prolonged labour, but this was based on the history given by the patient as there was no documentation of data in most cases, hence there could be a recall bias. The commonest presenting complaint in our study was of vaginal bulge/mass $(86.83 \%)$, as well as in a study conducted by Barber MD et al. ${ }^{17}$ Comparison between other presenting complaints is illustrated in Table 6. Thus, the presenting trend of symptoms in our study matched the existing literature. ${ }^{18,19}$ The data collection regarding etiology of defects in pelvic floor was comprehensive and satisfactory, we had comparable results with the studies already established in literature. The highest prevalence was found in the age group 60-64 years, the most common symptom was found to be mass per vagina, and grade 3 prolapse was the commonest amongst uterine prolapse and grade 2 in both cystocele 
and rectocele. Association of different predisposing and precipitating factors was found especially the modifiable ones such as smoking/tobacco use, constipation, chronic cough/asthma, diabetes, multiparity and prolonged labour. Maximum association was found with prolonged labour.

\section{CONCLUSION}

This study was aimed at assessing the prevalence and risk factors associated with pelvic organ prolapse in Indian women so that it could help in building up the literature and formulate better prevention and management plans to cater to the increasing aging population. It would also help in counselling and creating awareness amongst the general population regarding a widespread disease like pelvic organ prolapse, as the patients we see in our clinics are just the tip of the iceberg. Large epidemiological studies reflecting the overall situation of the country are the need of the hour.

Funding: No funding sources

Conflict of interest: None declared

Ethical approval: The study was approved by the Institutional Ethics Committee

\section{REFERENCES}

1. Maldonado PA, Wai CY. Pelvic organ prolapse. new concepts in pelvic floor anatomy. Obstet Gynecol Clin North Am. 2016;43(1):15-26.

2. Roberts EH. Uterine prolapse. $\mathrm{Br}$ Med J. 1932;2(3756):1209.

3. Dietz HP, Scoti F, Subramaniam N, Friedman T, Shek KL. Impact of subsequent pregnancies on pelvic floor functional anatomy. Int Urogynecol $\mathrm{J}$. 2018;29(10):1517-22.

4. Ashton-Miller JA, DeLancey JOL. On the biomechanics of vaginal birth and common sequelae. Annu Rev Biomed Eng. 2009;11(1):163-76.

5. Dietz HP. Prolapse worsens with age, doesn't it? Aust N Zeal J Obstet Gynaecol. 2008;48(6):587-91.

6. Vergeldt TFM, Weemhoff M, IntHout J, Kluivers KB. Risk factors for pelvic organ prolapse and its recurrence: a systematic review. Int Urogynecol J. 2015;26(11):1559-73.

7. AUGS. $26^{\text {th }}$ Annu Sci Meet Am Urogynecologic Soc. 2005;11:1-55.

8. Carley ME, Schaffer J. Urinary incontinence and pelvic organ prolapse in women with Marfan or Ehlers-Danlos syndrome. Am J Obstet Gynecol. 2000;182(5):1021-3.

9. Herschorn S. Female pelvic floor anatomy: the pelvic floor, supporting structures, and pelvic organs. Rev Urol. 2004;6(Suppl 5):S2.
10. Wu JM, Vaughan CP, Goode PS, Redden DT, Burgio KL, Richter HE, et al. Prevalence and trends of symptomatic pelvic floor disorders in U.S. women. Obstet Gynecol. 2014;123(1):141-8.

11. Barber MD, Burgio KL, Kenton K, Meikle S, Schaffer J, Spino C, et al. Prevalence of Symptomatic Pelvic Floor. JAMA. 2014;300(11):1311-6.

12. Rortveit G, Brown JS, Thom DH, Van Den Eeden SK, Creasman JM, Subak LL. Symptomatic pelvic organ prolapse: prevalence and risk factors in a population-based, racially diverse cohort. Obstet Gynecol. 2007;109(6):1396-403.

13. Swift SE, Tate SB, Nicholas J. Correlation of symptoms with degree of pelvic organ support in a general population of women: what is pelvic organ prolapse? Am J Obstet Gynecol. 2003;189(2):372-7.

14. Vergeldt TF, Notten KJ, Kluivers KB, Weemhoff M. Recurrence risk is associated with preoperatively advanced prolapse stage: Is there a difference between women with stage 2 and those with stage 3 or 4 cystocele? Int Urogynecol J. 2017;28(7):983-7.

15. Moalli PA, Talarico LC, Sung VW, Klingensmith WL, Shand SH, Meyn LA, et al. Impact of menopause on collagen subtypes in the arcus tendineous fasciae pelvis. Am J Obstet Gynecol. 2004;190(3)620-7.

16. Durnea CM, Khashan AS, Kenny LC, Durnea UA, Smyth MM, O'Reilly BA. Prevalence, etiology and risk factors of pelvic organ prolapse in premenopausal primiparous women. Int Urogynecol J Pelvic Floor Dysfunct. 2014;25(11):1463-70.

17. Barber MD, Visco AG, Weidner AC, Amundsen CL, Bump RC. Bilateral uterosacral ligament vaginal vault suspension with site-specific endopelvic fascia defect repair for treatment of pelvic organ prolapse. Am J Obstet Gynecol. 2000;183(6):1402-11.

18. Rortveit G, Subak LL, Thom DH, Creasman JM, Vittinghoff E, Van Den Eeden SK, et al. Urinary incontinence, fecal incontinence and pelvic organ prolapse in a population-based, racially diverse cohort: Prevalence and risk factors. Female Pelvic Med Reconstr Surg. 2010;16(5):278-83.

19. Miedel A, Tegerstedt G, Maehle-Schmidt M, Nyren O, Hammarstrom M. Nonobstetric risk factors for symptomatic pelvic organ prolapse. Obstet Gynecol. 2009;113(5):1089-97.

Cite this article as: Parulekar MS, Parulekar SV. Analysis of epidemiological factors for pelvic floor defects in Indian women. Int J Reprod Contracept Obstet Gynecol 2020;9:2492-7. 